\title{
Partnership in practice: making conservation work at Bezà Mahafaly, southwest Madagascar
}

\author{
Alison F. Richard' and Joelisoa Ratsirarson"
}

\section{ABSTRACT}

Bezà Mahafaly has been the site of a partnership for conservation since 1975, long before the idea of community-based conservation became widely accepted in Madagascar or elsewhere in the world. Today, the Bezà Mahafaly Special Reserve protects 4,600 ha of riverine, transitional and spiny forest with a rich endemic fauna. This paper provides a summary of the thirty-seven year history of the initiative, focusing on three issues: our evolving interpretation of the term 'community', the integral role of politics and economics in developing the partnership, and the linkage between local, regional and national influences that were experienced in some contexts as constraints and in others as opportunities. We draw five conclusions that we hope will be of interest to those engaged in similar activities in Madagascar and elsewhere: (i) the importance of relationships and trust, and the length of time it takes to build both; (ii) the inherent fragility of community-based collaborations, which depend heavily on particular individuals and the pressures on people's lives; (iii) the importance of sustained financial inputs and challenge of diversifying these inputs; (iv) the need for mechanisms to distribute costs and benefits that are accepted as fair, and for methods to track that distribution; and $(v)$ the central roles of improvisation and opportunism in the face of high levels of uncertainty, and the unanticipated key role played by a village-based environmental monitoring team.

\section{RÉSUMÉ}

Bezà Mahafaly a été le site sur lequel un partenariat pour la conservation de la nature a œuvré depuis 1975, à savoir bien avant que n'émerge l'idée de la conservation basée sur la participation de la communauté locale qui est maintenant acceptée à Madagascar et ailleurs dans le monde. Aujourd'hui, la Réserve Spéciale de Bezà Mahafaly protège 4600 ha de forêts galeries, de forêts de transition et de forêts épineuses qui abritent une faune endémique d'une grande richesse. Le partenariat engage la Commune d'Ankazombalala, I'Université d'Antananarivo et ses collaborateurs internationaux, et Madagascar National Parks. Dans cet article, nous présentons un aperçu sur I'historique de cette initiative, après lequel nous considérons trois

\author{
Correspondence: \\ Alison F. Richard \\ Yale University, Department of Anthropology \\ PO Box 20877, New Haven, CT 06520-0877, U.S.A. \\ E-mail: alisonfrichard@gmail.com
}

questions. La première question porte sur l'évolution de notre interprétation du terme 'communauté'. Pendant les premières décennies, nous englobions surtout sous ce terme les autorités locales, les chefs traditionnels ou les chefs des associations villageoises. Notre compréhension est plus globale aujourd'hui, mais nous pouvons admettre que nous aussi, les universitaires et les agents de Madagascar National Parks, représentons une 'confusion communautaire' aux yeux des gens de la Commune. La seconde question aborde le rôle intégral de la politique locale et de l'économie dans le développement du partenariat. Le récit historique comprend quatre phases qui correspondent largement aux changements d'approches caractérisant I'initiative depuis son début : conclure un marché, chercher la réciprocité, forger la collaboration et lancer un vrai partenariat équilibré pour la conservation de la nature. L'engagement politique au niveau local était fondamental pour nos efforts à partir de 1975 et rendait des services économiques qui ne portaient pas directement sur la conservation de la nature. Loin de représenter une défaite, ces activités étaient essentielles pour former le partenariat. Enfin, la troisième question concerne les relations entre les influences locales, régionales et nationales, que nous avons parfois ressenties comme des contraintes, mais également comme des opportunités à saisir. En 1975, une grande tension existait entre les buts poursuivis par le partenariat et le contexte législatif national car ce dernier imposait des aires protégées vues 'd'en haut'. L'isolement de Bezà Mahafaly et I'intervention des universités ont pu atténuer en partie le poids de cette hiérarchie. La politique nationale de décentralisation des années 1990, par contre, a renforcé les activités sur le terrain. Pour conclure, nous détaillons cinq considérations qui pourraient servir à de futurs efforts : (i) l'importance de la confiance mutuelle qui dépend des relations humaines et se met en place avec le temps ; (ii) la fragilité des collaborations communautaires qui dépendent de certaines personnes bien particulières et des contraintes de la vie quotidienne de la population; (iii) I'importance des appuis financiers à long terme ainsi que l'obligation inhérente de les diversifier; (iv) la nécessité de mettre en place des mécanismes pour partager les avantages ainsi que les coûts des efforts qui soient acceptables aux yeux 


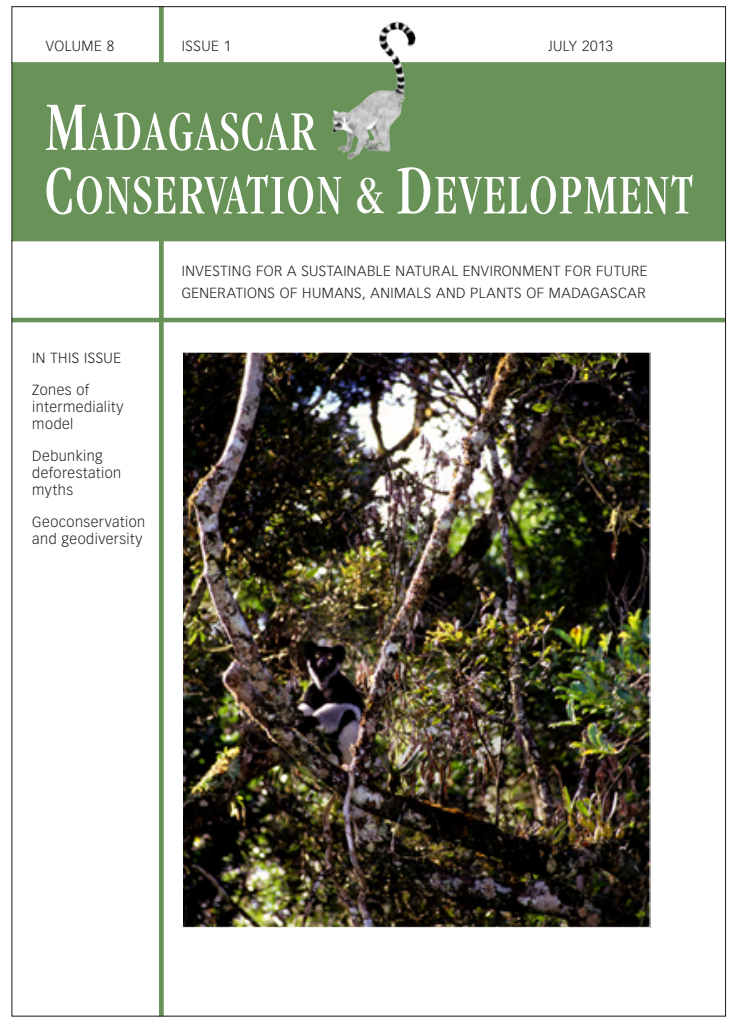

Madagascar Conservation \& Development is the journal of Indian Ocean e-Ink. It is produced under the responsibility of this institution. The views expressed in contributions to MCD are solely those of the authors and not those of the journal editors or the publisher.

All the Issues and articles are freely available at http://www.journalmcd.com

Contact Journal MCD

info@journalmcd.net for general inquiries regarding MCD funding@journalmcd.net to support the journal

Madagascar Conservation \& Development Institute and Museum of Anthropology University of Zurich

Winterthurerstrasse 190

CH-8057 Zurich, Switzerland

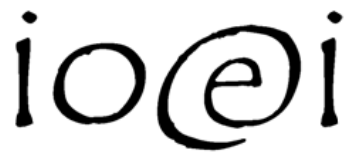

Indian Ocean e-Ink

Promoting African Publishing and Education www.ioeink.com

Missouri Botanical Garden (MBG)

Madagascar Research and Conservation Program BP 3391

Antananarivo, 101, Madagascar 
de la communauté ; (v) l'importance capitale de l'improvisation et de l'adaptation face aux incertitudes, et le rôle clé mais inattendu dans la formation du partenariat à Bezà Mahafaly qui a été joué par une équipe villageoise dans le suivi de l'environnement.

\section{INTRODUCTION}

The 4,600 hectares Bezà Mahafaly Special Reserve in southwest Madagascar is among those in Madagascar's Protected Area System recognized by a temporary inter-ministerial order issued in 2008 and renewed in 2010. The initial 600 hectares of the Reserve was established by government decree in 1986. The Reserve is sustained by a partnership between the community of Ankazombalala, the School of Agronomy of the University of Antananarivo and its international collaborators, and Madagascar National Parks. A Steering Committee composed of local, regional and national representatives brings the partners to a single table to make strategic decisions and provide general oversight. Within the community, the Reserve is protected through a customary agreement, or dina. The dina has provided crucial protection for the Bezà forests and wildlife since the national political crisis erupted in 2009.

Efforts to build the Bezà Mahafaly partnership began in 1975 and have continued without interruption. Drawing on this unusually long history against a backdrop of changing national policy and legislation, our paper assesses the relevance and influence of those changes on the partnership's evolution, and contributes to recent discussions about the effectiveness of community-based collaborations with conservation goals in Madagascar (e.g., Raik and Decker 2007, Pollini and Lassoie 2011).

The importance of involving communities in the management of natural resources and conservation of biodiversity gained serious attention in much of the world, including Madagascar, only about 20 years ago (Western and Wright 1994). State-imposed programs had proven ineffective in earlier decades, despite substantial investments and support for high recurrent costs; weak central government made the failure bigger, but it turned out that even strong central governments had limited capacity to coerce their citizens into compliance with unpopular programs: top-down conservation did not work (Wells and Brandon 1992, Agrawal and Gibson 1999, Durbin et al. 2003, Randriamalala and Liu 2010, Pollini 2011). Political and moral arguments were also brought to bear: people living on the land should certainly have a voice and, perhaps, ultimate control in its disposition (Peters 1998). Reflections on the nature of symbolic relationships between people and nature wove their way into the case for community-based conservation, too (Western and Wright 1994, see also review by west et al. 2006).

The shift from 'top-down' to 'bottom-up' approaches cannot ignore the inevitable and necessary linkages between community-based conservation and national policy and legislation (Gezon 1997, Horning 2008). Despite significant effort and some progress, making those linkages work well remains a challenge in Madagascar (Blanc-Pamard 2009, Andriamalala and Gardner 2010, Pollini 2011, Hanson 2012). Accumulating legislation has created a thicket of rules that are sometimes in conflict with one another, and tensions between sectors over national policy priorities create further confusion on the ground, as in many countries.
Several authors have also pointed out that a 'one size fits all' approach to community-based conservation is untenable. Although patches of forest and certain animal species are protected by fady (taboos) in some rural communities (e.g., Lingard et al. 2003, Tengö et al. 2007), communities have their own distinctive histories and internal dynamics, with divergent consequences for their capacity to manage natural resources and achieve conservation goals (e.g., Horning 2003, 2008, Ormsby and Kaplin 2005, Gezon 2006, Elmqvist et al. 2007, Toillier et al. 2011). We note too that most community-based conservation initiatives are in fact collaborations, as at Bezà Mahafaly, with the nature of the collaborator(s) and relationships formed adding further diversity.

The late Professor Gilbert Ravelojaona, then President of the School of Agronomy (École Supérieure des Sciences Agronomiques - ESSA) at the University of Antananarivo, made many of the arguments for community involvement in conservation long before they became widespread, and his vision helped inspire the Bezà Mahafaly initiative in 1974. That year, Guy Ramanantsoa (University of Antananarivo), Robert Sussman (Washington University) and AR (Yale University) decided to search for a rural community interested in a collaboration that would have three goals: (i) protecting the community's forests and wildlife, (ii) improving the livelihoods of community members, and (iii) developing a site for training and research. The Ankazombalala community, eventual home of the Bezà Mahafaly Special Reserve, became the universities' collaborator and partner.

The partnership made for considerable 'learning by doing' in the absence of comparable efforts for much of its long history. This paper documents some of the lessons learned, particularly with respect to the first two goals. While agreeing with other authors that no single model will work everywhere, we believe that community-based conservation activities in Madagascar have much in common and that it is useful to share experiences and identify commonalities. After introducing the Commune of Ankazombalala and presenting a brief history of the partnership, we discuss three issues: (i) The meaning of 'community': Decisions about partnership goals were always approved by the commune, the formal administrative unit recognized by the government; over time, however, decisions came to be reached through informal discussion and negotiation with a wide array of people - the 'community'. We use the word loosely and interchangeably with fokonolo (in Mahafaly dialect). Struggling to understand with whom and how we should be collaborating, our experiences taught us the diverse meanings of these words and exposed tensions between the formal processes of the commune and the informal processes of the fokonolo. As our grasp of these complexities increased, it certainly shaped and changed the way we worked. We attempt to capture this dynamic here. (ii) Phases in the development of the partnership: We identify four phases in the partnership's history; during the first, a bargain was struck, grounded in expectations of reciprocity; during the second, the universities attempted to establish reciprocity in practice as well as principle, with mixed results; out of these efforts grew real collaboration in the third phase; and from collaboration came a partnership for conservation in the fourth. Political and economic considerations were more important to the commune than conservation at the outset, and they weighed heavily in developing the partnership. Based 
on the Bezà Mahafaly case study, solid political and economic foundations are crucial underpinnings of community-based collaborations for conservation. (iii) Local partnership and national law: Many levels and spheres of authority and influence interacted and were reconfigured at Bezà Mahafaly during its 37 -year history. Local leadership was rooted in local history and custom or conferred by the formal structures of government, and sometimes both. The authority accorded each by the community shifted, depending on many factors including the character of incumbents. Meanwhile, highly centralized legislative controls were progressively devolved to non-government institutions and communities. We explore how this shifting, complicated political and legislative web both encouraged and constrained our partnership with the community.

The materials on which this paper draws include the published work of Malagasy and international students and researchers; systematic information collected by the Bezà Mahafaly Monitoring Team since 1995 (Ratsirarson et al. 2001); previously published historical perspectives (Sussman et al. 1994, Richard and Dewar 2001, Ratsirarson 2003, 2008, Sussman et al. 2012); unpublished external evaluations and reports; and the record of progress, setbacks and reflections contained in annual reports to the Malagasy authorities and the funding agency. We also draw upon our own experiences (AR since 1975, JR since 1985).

\section{ANKAZOMBALALA COMMUNE.}

Southwest Madagascar, location of the Ankazombalala Commune, was one of the poorest regions of the island in 1975, and it remains so today (Minten et al. 2003). In the area of the Commune, annual rainfall has averaged $460 \mathrm{~mm}$ over the last decade. Most rain falls between November and March, but the pattern and volume are highly unpredictable from year to year and, like the 'deep south', southwest Madagascar experiences intermittent droughts (Dewar and Richard 2007, Rasamimanana et al. 2012). These conditions pose challenges for pastoralism and agriculture, the two main subsistence occupations of Commune residents. The challenges are compounded by limited access to the regional market in Betioky Atsimo (E44 $23^{\prime} \mathrm{S} 23^{\circ} 43^{\prime}$ ) due to poor roads and transportation, high levels of illiteracy, and lack of primary health care. Although progress has been made since 1975 , food security remains a major preoccupation and concern.

The Commune encompasses an area of about 400 square kilometers. Administratively, it is one of 27 under the jurisdiction of the District of Betioky Atsimo, itself one of four Districts in the Region of Atsimo-Andrefana. The Commune comprises 17 villages recognized administratively as fokontany (Figure 1); many are widely scattered in hamlets. People mostly describeurrent na themselves as Mahafaly, but they make strong distinctionścoles between clans. Census data are difficult to obtain and of uncertain accuracy. The Commune population was estimated at 8,099nkazombalala in 1993 (Commune records), 8,216 in 2001 (ILO/FOFIFA/INSTATMadagascar National Parks 2001), and 13,900 in 2006 (Randrianandrasana, unpubl.).

Located in the center of the Commune landscape, thegion Province 2008 Bezà Mahafaly Special Reserve $\left(\mathrm{E} 44^{\circ} 23^{\prime}, \mathrm{S} 23^{\circ} 43^{\prime}\right)$ is named fokommune Firaisana 2008 a village ten kilometers away. When the Reserve was inaugurated in 1985, it comprised 600 hectares in two non-contiguous patches within a larger forest, their boundaries separated by over $1.5 \mathrm{~km}$. In 2006, the Commune approved the Reserve's extension to encompass the two patches in 4,600 hectares

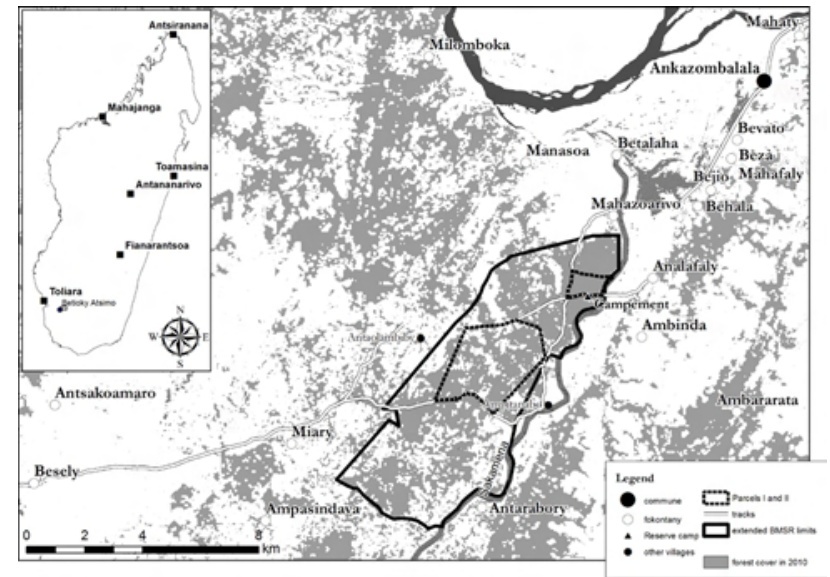

FIGURE 1. Boundaries of Ankazombalala Commune and the Bezà Mahafaly Special Reserve.

(Figure 1). Descriptions of the Reserve's ecology and biodiversity can be found in Ratsirarson et al. (2001), Ratsirarson (2003, 2008), and Sussman et al. (2012).

\section{A BRIEF HISTORY OF THE PARTNERSHIP}

The names of some institutions have changed since 1975 (Table 1). We use current names here. Table 2 summarizes relevant changes in national legislation, policies and institutions from 1975-2012, alongside changes in the configuration of responsibilities at Bezà Mahafaly. The following account gives further detail and a glimpse of the human dynamics.

In 1974, the universities' first challenge was to find a community willing to work in partnership. Guy Ramanantsoa, the then Department Head, journeyed far in an oxen cart before meeting the Mayor of Ankazombalala Commune, who found his proposal attractive. Seeking the community's support, the Mayor emphasized economic benefit rather than conservation, though community members regarded the forest and many of its animals as fady.

In 1975, all but one of the fokontany gave their support to the proposed collaboration. A bargain was struck between the two founding partners, who actually had quite different interests: "we agree to help you protect the forest, but our primary interest is economic development" (the commune), and "we agree to help you improve your economic circumstances, but our primary interest is conservation" (the universities). The two sides of the bargain were not directly connected, since anticipated economic improvements were not selected to reduce pressures on the forest (Richard and Dewar 2001, see also Pollini

TABLE 1. Changes in names of institutions involved in the partnership since 1975. Supérieure des Sciences Agronomiques Établissement de I'Enseignement supérieure des Sciences Agronomiques 1986 University of Madagascar 2006 Association Nationale pour la Gestion des 2008 
TABLE 2. Changes in relevant national legislation, policies and institutions, and in the configuration of responsibilities at Bezà Mahafaly, 1975-2012. (ESSAForêts: Department of Forestry, School of Agronomy; WWF: World Wildlife Fund; MNP: Madagascar National Parks; GELOSE: Secured Local Management; COSAP: Protected Area Oversight and Management Committee; KASTI: Community Conservation Committee).

\begin{tabular}{|c|c|c|}
\hline Year & Management arrangement & Statutory authority \\
\hline 1975 & $\begin{array}{l}\text { Universities of Antananarivo, Washington, and Yale } \\
\text { academics establish inter-university partnership }\end{array}$ & $\begin{array}{l}\text { Land belongs to Government through Ministry in charge of forest domain; } \\
\text { forest use regulated by local state agents and customary laws }\end{array}$ \\
\hline 1986 & $\begin{array}{l}\text { ESSA-Forêts receives delegated authority to manage } \\
\text { Reserve from Ministry in charge of Forest Domain; } \\
\text { Government retains ownership, and supervision and } \\
\text { enforcement roles }\end{array}$ & Reserve formally established under the decree \# 86-186 \\
\hline 1989 & $\begin{array}{l}\text { ESSA-Forêts enters co-management agreement with } \\
\text { WWF }\end{array}$ & Statutory authority unchanged \\
\hline 1990 & $\begin{array}{l}\text { ESSA-Forêts/WWF co-management continues after } \\
\text { creation of MNP }\end{array}$ & $\begin{array}{l}\text { MNP established to oversee and manage all protected areas, and help imple- } \\
\text { ment National Environmental Plan; Ministry in charge of the Forest Domain } \\
\text { retains statutory ownership and responsibility for law enforcement }\end{array}$ \\
\hline 1994 & ESSA-Forêts resumes sole management & \\
\hline 1996 & Arrangements unchanged & GELOSE legislation enacted \\
\hline 2005 & $\begin{array}{l}\text { MNP assumes management of Reserve, with ESSA } \\
\text { Forêts responsible for research and training }\end{array}$ & Statutory authority unchanged \\
\hline 2008 & & $\begin{array}{l}\text { Extended Reserve provided temporary protection by Inter-Ministerial Order \# } \\
\text { 18633/2008/MEFT/MEM }\end{array}$ \\
\hline 2009 & $\begin{array}{l}\text { COSAP established for joint oversight of all activities with } \\
\text { all partners; KASTI reinforced for patrol and surveillance }\end{array}$ & \\
\hline 2010 & & Inter-Ministerial Order providing temporary protection renewed, \#52005/2010 \\
\hline 2012 & $\begin{array}{l}\text { Renewal of MNP/ESSA partnership formalized for another } \\
5 \text { years }\end{array}$ & \\
\hline
\end{tabular}

and Lassoie 2011). After this first agreement, the universities worked with the Mayor and his advisors toward statutory protection of the forest. In 1984, once again all but one of the fokontany supported the proposal. Members of the dissenting fokontany used part of the 'protected' forest for grazing, and viewed the reserve as an unacceptable encroachment on their rights. With the support of the majority of municipality committee member, however, the Mayor submitted the proposal through legislative channels, followed by direct petition from the commune to the central government.

These two key decisions, in 1975 and 1984, were rare moments of almost unanimous accord among the political leaders of the Commune and its constituent fokontany. The commune was fragmented and filled with contention, reflecting diverse views within the fokontany as well as differences among the leaders themselves. Fokontany distant from the Reserve complained that they benefited little from the arrangement; fokontany nearby complained that outlying villages bore few of the opportunity costs of the partnership and benefited too much from its presence, and the naming of the Reserve for a distant village (and home of the Mayor) was a further grievance.

The Bezà Mahafaly Special Reserve was nevertheless established by national decree in 1986 (decree n 86-168 in June 1986). Under the circumstances, the support of the fokontany and Commune seemed ill-deserved: The change made the forest's reserved status permanent, with little evidence that the universities were honoring their side of the bargain. We infer that support was driven by several considerations: local expectations were low, and needs were high; a few things had been 'delivered' by the universities despite the limited capacities, and perhaps more would be coming; the seeds of a relationship had been planted with a few key leaders in the community, and wariness coupled with fearfulness made people reluctant to take on their own leaders or the outsiders with whom those leaders were aligned.

Three developments opened up new opportunities for the universities to make good on their initial commitment to the Commune: (i) international aid to Madagascar increased greatly after 1982; (ii) large-scale, integrated conservation and development projects became a priority for that aid; and (iii) Madagascar was established as a global 'biodiversity hotspot' (Mittermeier 1988, Mittermeier and Bowles 1993).

With USAID funding, the universities were now able to address the Commune leaders' two most urgent priorities: improvements to the road to the weekly market in Betioky, and irrigated water for rice cultivation. The first effort met with modest success. The second did not (Sussman et al. 1994). Good faith with little follow-up had become good faith with counterproductive intervention.

The role of ESSA-Forêts at Bezà Mahafaly underwent two changes during this period. WWF-Madagascar, which provided core funding at the time, pressed for a co-management arrangement. Madagascar National Parks (MNP), established to oversee the national network of protected areas including the Bezà Mahafaly Special Reserve, delegated management of the Reserve to ESSA-Forêts (and WWF) but established new conditions: Reserve entrance fees were to be remitted to MNP headquarters, with half the income put in escrow to fund community projects. In effect, the arrangement established a tense, sometimes confusing truce between MNP and ESSAForêts, and maintained the Reserve's anomalous position within the national network.

Dismayed by the outcome of a large-scale canal project in late 1980's, the universities refocused on small-scale activities initiated and implemented by individuals within the fokonolo. These activities were still largely separate from conservation in their goals, but differed in two ways from the few undertaken in 
earlier years: They involved local associations instead of political leaders, and enlisted the collaboration of regional authorities and non-governmental organizations (NGOs) with specific expertise, instead of relying on the universities alone. The new approach made it easier to engage interested and energetic men and women, and circumvented the difficulties and conflicts of the formal political structure. Funds from the first Debt for Nature swap in Madagascar brokered by WWF-Madagascar provided a bigger core budget from 1994-2001.

Newly founded village associations, including three established by and for women, drove a proliferation of small-scale activities, supported by grants from external sources and micro-financing arrangements improvised by the universities. The results were mixed. A few initiatives succeeded, such as a primary care program, new primary schools and wells, and they benefited many in the fokonolo. Several associations faded away after an initial burst of enthusiasm, however, and many initiatives failed through bad luck or poor conception: chicks purchased as poules pondeuses (laying hens) grew up to crow, for example; technical improvements in crop storage facilities proved less effective against rodents than the presence of a cat, and did not prevent insect damage.

A more fundamental problem was that the approach sidelined the Commune's political leadership. At a stormy meeting in 1998, the Mayor made it clear that there would be no partnership without his active involvement. A shared interest in gaining access to the funds held in escrow by Madagascar National Parks (MNP) provided an apparent way forward: The Mayor and his colleagues, leaders of the fokontany and local associations, and the universities would all work together to establish a Local Management Committee (COGES), declared a condition of access to the funds by MNP. In the event, a protracted conflict ensued among fokontany over which should be included and represented on the Committee. The COGES was finally established in 2003. Reaching agreement had taken four years and the election of a new Mayor, with the authority and will to resolve the impasse.

Seemingly far removed from such issues, the Bezà Mahafaly Environmental Monitoring Team was launched by the universities in 1995. There was still much to learn about the forest and wildlife, and the nature of threats to their survival. The team in charge of the Monitoring activities (Monitoring Team) would help with that task. With support from LCAOF (Liz Claiborne and Art Ortenberg Foundation), its members were recruited from villages around the Reserve and had little formal schooling, but they knew the forest well and cared deeply about its future. Led by ESSA-Forêts, the Monitoring Team gathered systematic data on climate, biodiversity, and the demography, socio-economy, and perceptions of the fokonolo. They became highly expert in these tasks and also de facto ambassadors to and from their villages. When debt-swap funds ran out in January 2001 and national political turmoil brought normal functioning to a halt, the Monitoring Team worked on, supported by LCAOF.

In 2003, MNP provided funds and staff to re-establish a stronger presence at the Reserve, and became a full third partner. This was much needed. Despite the Monitoring Team's efforts, a small group of villagers had made a clearing and planted maize in the southwest corner of the Reserve, and the partnership between the universities and the community seemed to be faltering. In addition, new fields had been opened up illegally in the surrounding forest, making it a high priority to extend the Reserve and connect its two non-contiguous parcels of forest. MNP and ESSA-Forêts launched an intense effort to win the support of the fokonolo, through conversation, debate, negotiation, and public service broadcasts by the Monitoring Team from a radio station in Betioky Atsimo. The many collaborative relationships already in place provided a foundation for renewed, urgent discussions about conservation and the value of the forest.

In 2006, agreement on new boundaries for the extended Reserve was reached with the fokonolo and subsequently approved by the leaders of fokontany and the commune. The original Reserve forests remained totally protected, and other parts of the extended Reserve were zoned for co-management and controlled use by the fokontany to meet their domestic needs, including pasture, and the harvest of forest products for construction, medicine and food.

Several mechanisms were established locally to uphold and implement the agreement. An MNP-mandated committee was set up to monitor management of the Reserve (Comité d'Orientation et de Suivi des Aires Protégées - COSAP). The majority of the 24 members were chosen from and by the five fokontany closest to the Reserve, with a locally elected Chairman, and the rest of the committee was made up of regional and national representatives including ESSA-Forêts and MNP. In parallel, the fokonolo established a dina, or customary agreement, subsequently endorsed by the Commune. The dina provided a local framework for protection and enforcement, with a village conservation committee (Komitin'ny Ala Sy ny Tontolo lainaina - KASTI) set up to patrol the forest, report infractions, and attempt to identify the culprits. A group of respected elders was designated by the fokonolo to hear cases and impose penalties. The idea of the dina came from the fokonolo and had broad buy-in (cf. Kull 2002). It was a great advance, but also a fragile defense: The dina had no power over people passing through the area, and family ties and fear of reprisal limited its effectiveness within the fokonolo (cf. Andriamalala and Gardner 2010).

With the extension of the Reserve came assurances from the universities and MNP of continuing investments that would partly offset the impact of new restrictions, but the political crisis in 2009 meant that, for the second time in Bezà Mahafaly's history, it became difficult to honor a commitment made in good faith. Compliance with the rules of the dina remained high, nevertheless. This could be because community members saw compliance as a necessary condition for their economic expectations to be met in the long term, or because a real 'partnership for conservation' had been forged. Household survey data suggest that both interpretations are warranted.

\section{DISCUSSION}

THE MEANING OF 'COMMUNITY'. The Bezà Mahafaly partnership was a highly political undertaking in the first two decades (Richard and Dewar 2001). For the universities, the question 'who is our partner?' was more about local leadership than inclusiveness, and more about practical outcomes than community. It was a matter of identifying and then working with individuals who were best able to resolve disputes, take decisions, and make things happen. The universities initially looked to Commune leaders to play this role, particularly the Mayor, and subsequently to the founders and members of local 
associations created for specific purposes. 'Community' was a convenient if misleading way of referring to these individuals.

A broader, more flexible approach has emerged since then, embracing the formal and customary political leadership, local associations, interested individuals, people who have become friends, and - as in all protected areas - two new entities, the COSAP (a committee for the monitoring of the management of the Reserve) and KASTI (a village conservation committee). The benefit is that this has made the partnership more inclusive and effective, but it comes at a cost: maintaining an extensive web of relationships and the structures embedded within them is time-consuming, and makes decision-making a highly iterative process. The arrangement is also fragile, for it depends heavily on the goodwill and leadership of particular individuals over long periods of time, and on sustained external financial support.

Over the years, our reservations about using the word 'community' have grown (cf. West et al. 2006), though we have yet to find an alternative. The Ankazombalala community has developed informal ways of establishing agreement and negotiating compromise more effectively than in the past, and has accorded the universities and MNP a role in those processes. Still, unresolved disagreements and conflicts of interest remain common between households, clans, and fokontany. It is easy to get caught in the middle of arguments, and difficult to reach decisions with confidence that they are widely supported. For anyone who has worked with a small community in any context in any part of the world, none of this is news.

The abstraction of real world, complex communities into idealized entities is a frequent feature of community-based conservation collaborations, and a common source of ensuing disappointment and frustration for those involved. It also makes the effectiveness of community engagement difficult to evaluate: Individuals or groups can usually be found who object to actions taken on their behalf, and Bezà Mahafaly is no exception.

Many issues raised in this section also caused puzzlement and disagreement among members of the Ankazombalala community. The fokonolo is not a fixed entity for them either (cf. Pollini and Lassoie 2011). The four-year argument about who had the right, through COGES, to participate in and benefit from decisions about funds held in escrow by MNP is an example of that uncertainty. Moreover, from the standpoint of the fokonolo, who were and are we, 'the universities', with the eventual addition of MNP? We have no data to trace a history of their answers to this question and would struggle to answer it cogently ourselves. Community members have come to use the name Antanambazaha (village of outsiders) for the field station, suggesting that they have found a place for us in their social landscape. It is an ambiguous name, to be sure, and the likely reality is that we are as complicated a fokonolo in their eyes as they are in ours.

PHASES IN THE DEVELOPMENT OF THE PARTNERSHIP.

The history of the Bezà Mahafaly partnership can be roughly divided into four phases: striking a bargain (1975-1985), reaching for reciprocity (1985-1993), working at collaboration (1993-2003), and establishing a partnership for conservation (2003 to the present). This framework began to take shape in our thinking about a decade ago (Richard and Dewar 2001). Although our long-term goals were clear (to us, anyway) from the outset, in practice we constantly improvised in our attempts to achieve them. The four phases are not mutually exclusive, but reflect chronological shifts of emphasis made possible by events on the ground and in national and international arenas. Political engagement was central to the initiative's founding and, for most community members, came before they had any direct involvement. It yielded economic objectives that had little to do with biodiversity. We do not view this as evidence of failure, but rather as a necessary and integral part of the process. More complex transactions and the development of shared conservation goals were built upon the rudimentary, bumpy political and economic activities of the first years.

Partnership relationships are very different today from those 37 years ago. We have become neighbors of sorts, within the community's social landscape. Community members stop by to gossip and we return their visits; deaths bring everyone together; we help one another out in simple ways. Increasingly, these informal exchanges touch upon the forest and its protection. We have also become close collaborators on development initiatives. These interactions do not bear directly on our partnership for conservation, but they sustain and reinforce it.

Household surveys carried out by the Monitoring Team in 1999 and again in 2010 substantiate these evolving dynamics. The team held structured conversations with members of 346 (1999) and 200 (2010) households in the fokontany closest to the Reserve, during which they asked men and women how the forest was of value to them, and about their perceptions of the partnership (Ratsirarson et al. 2001). The importance of the forest in people's daily lives emerged clearly in both surveys, as a source of firewood, timber, medicinal plants and food, in addition to being a place for hiding cattle from rustlers. In 2011, most (>80\%) of those interviewed also commented that the forest was important as a heritage for their children and grandchildren.

Perceptions of the partnership's importance in conserving the forest changed markedly between the two surveys. In 1999, the most frequent and often only reported benefit of the partnership was occasional access to a car to go to the market or the hospital. In 2010, the great majority (>90\%) talked positively about the partnership's role in protecting the forest, and considered themselves as actively contributing to the effort. Remaining skeptics or opponents came overwhelmingly from the fokontany that had opposed the Reserve from the beginning.

The participation of community members in conservation activities is almost always compensated with small payments, but the transaction is more an exchange than a matter of employment in the prevailing non-cash economy: People 'choose to join in', and are thanked in kind. The Young Athletes Association in one fokontany is an exception: In recent years, its members have volunteered to help patrol the Reserve and keep trails open without remuneration.

We doubt that a partnership for conservation would have emerged faster if we had started out with the framework described here, but it would have helped us proceed more deliberately on a long-term course of action. Even though largely unarticulated, however, the strategy achieved the first goal set when the partnership was established: Protection of the area's unique forests and rich wildlife. It has also driven progress toward the second goal, improving people's livelihoods, through advances in health and education in particular. The continued existence of the forest is itself viewed as a tangible benefit by many. Defining and mapping the distribution of these benefits, and their costs, within the fokonolo remains a task for the future. 
LOCAL PARTNERSHIP AND NATIONAL LAW. The Bezà

Mahafaly partnership was launched in a legislative context that had changed little since the time of the French colonial administration. Deeply antithetical to the top-down approach of that period, initial work toward the partnership was shielded from national politics and law, because the forest was to be protected as a field station for students and researchers (terrain d'application) for ESSA-Forêts, under a simple Memorandum of Understanding between ESSA and the Ministry in charge of Forestry at the time (in the 1980's). The founding spirit of separation and separateness from national environmental strategy endured as a strength and a drawback. At the heart of the ambiguity lay the tension between the universities' aspiration to 'real' partnership, and the reality of management accountability conforming to national statutes. The ambiguity came to the fore in 1986, with statutory recognition of the Special Reserve, after which ESSA-Forêts carried out its responsibilities as the designated primary manager in what it saw as a spirit of partnership with the community - for which there was no legislative basis.

In light of these enduring ambiguities, one could have expected the founding spirit of partnership to fade away. But in fact the opposite happened. ESSA-Forêts and MNP staff have become part of the community's social landscape, many community members are actively involved in the partnership, and the field station has acquired its own informal name. The interests of the three partners are increasingly aligned, and although their roles are nominally distinct, in practice most of the work is shared.

Five factors helped this evolution, three local and two national: (i) The community's remoteness meant that people had little choice but to sort out problems together. (ii) As a result of the unusual organizational arrangements of the partnership, the universities brought a freewheeling culture into the mix that helped downplay the formal, bureaucratic aspects of management accountability. (iii) The Monitoring Team helped blur the contradictory features of the situation. In addition to their formal duties, Monitoring Team members served as knowledgeable intermediaries, the 'glue' that held the partnership together. (iv) A wave of change in national policy took place in the 1990's that would open new opportunities for the Bezà Mahafaly partnership and other grassroots activities. Its spirit was embodied in the GELOSE (Gestion Locale Sécurisée: Iocal secured management) legislation (n 96-025) adopted in 1996, permitting natural resource management transfers outside protected areas. The stipulations of the GELOSE legislation came to be viewed as complicated, burdensome, and administratively challenging, particularly for rural communities where many people had little or no formal education (Pollini and Lassoie 2011). Yet the legislation presented a broad shift toward decentralization, which influenced the management of protected areas as well as less regulated forests. It also highlighted a potentially important role for the dina, an institution deeply embedded in Malagasy culture. At Bezà Mahafaly, the effect has been to narrow the gap between the founding aspiration to partnership and the historical reality of centralized management oversight. (v) The commitment to expand Madagascar's protected areas to $10 \%$ of the island's surface made by former President Ravalomanana in his 2003 Durban Vision mobilized political energy, financial resources, and activity. Equally important, for the first time the world heard a President of Madagascar not just strongly assert the inestimable value of Madagascar's natural heritage but couple that assertion with a clear call to action. Even in the remote villages of southwest Madagascar, both messages were heard.

\section{CONCLUSIONS}

This article concerns a particular community and a particular period in Madagascar's history. Stepping back from our experiences, however, we draw five conclusions that we hope are relevant to other communities and forests: (i) Community-based collaboration: Building a 'community-based collaboration' is a long and slow process. Collaboration is a political activity based on mutual benefit, shared goals, perceived fairness, and trust. community-based collaborations involve quite small groups of people working with one another, and trust comes from relationships formed over extended periods of time. This requires individuals willing and able to make long-term commitments; career paths in academic institutions and small NGOs are unusual in making this possible, which may explain their prominence in community-based collaborations in Madagascar. Collaborative conservation initiatives need to be framed and designed with these fundamental considerations and potential constraints in view. (ii) Individual leadership: Community-based collaborations depend heavily on 'individual leaders', are inherently fragile as a result, and should make it a high priority to identify and encourage future leaders. In the case of Bezà Mahafaly, the death of a respected elder, election of a new mayor, or appointment of new university or MNP staff, could mean either a big step forward - or backward. Good governance cannot protect collaborations from the impact of individuals who are uninterested, inept, or corrupt - making it absolutely critical to keep finding people who are passionately concerned, competent, and honest. (iii) Sustained funding: Community-based collaborations need modest but 'sustained financial inputs'. Up to now, these inputs have mostly come from external sources, ranging from large international foundations and aid agencies to small philanthropic organizations. The 'fit' between large organizations and community-based collaborations is often poor, because of widely differing expectations of spatial scale and time frame. small philanthropies, in contrast, have played a crucial and sustained role in Madagascar, and Bezà Mahafaly has been among the beneficiaries of one of them. Looking to the future, locally generated inputs must become more important, in order to sustain the growing array of community-based, conservation collaborations now underway in Madagascar. Ecotourism and other local income streams offer the prospect of financial self-sufficiency in some contexts (e.g., Rabearivony et al. 2008, Harris 2011), and will surely help in many. Developing these income streams represents a major cultural as well as economic challenge, however. (iv) Shared costs and benefits: Communitybased collaborations need 'mechanisms for distributing costs and benefits' that are accepted as fair (cf. Sommerville et al. 2010). We worked to establish such mechanisms through the complex processes of deliberation and feedback described in our study, but lack systematic evidence of the actual distribution of costs, benefits, and inputs. A high priority is to develop and implement workable methods to assess this distribution, not only across the spatial and social scale of the Ankazombalala community but also through time. (v) Accepting the unexpected: 'Improvisation and opportunism' are essential strategic compo- 
nents of community-based collaborations because of the high levels of uncertainty involved (cf. Dewar and Richard 2012). The Monitoring Team provides the best example of this at Bezà Mahafaly. Team members were given the task of inventorying biodiversity and tracking environmental indicators, but they quickly recognized the gap between the aspirations of the partnership and the realities on the ground and set about filling it, with the encouragement of ESSA-Forêts. This was not planned, but it may be the most significant contribution to ideas about making community-based conservation work that Bezà Mahafaly history has to offer.

\section{ACKNOWLEDGMENTS}

We thank the Ankazombalala community for their willingness to embark on this endeavor, and keep thinking it was worthwhile. We salute the late Gilbert Ravelojaona who helped inspire the partnership, and the late Pothin Rakotomanga who worked hard at it for many years. Our enduring thanks go to Bob Sussman and Guy Ramanantsoa, without whom nothing would have happened in the first place. We gratefully recognize the ongoing collaboration with Madagascar National Parks, in particular the staff who have been on the ground at Bezà Mahafaly for the last decade. To the members and leaders of the Environmental Monitoring Team we owe a great debt of thanks: Helian Ratsirarson, Elysé Razanajaonarivalona, Sylvia Ravelonjatovo, Jeannica Randrianarisoa, Jacky Youssouf, Miandrisoa Razafindraibe, Emahalala Ellis, Edidy Ellis, Rigobert Jean Emady, Enafa, Elahavelo, Edouard, and Efitiria. We also thank Kashka Kubzdela, who trained Enafa and Rigobert Jean Emady as research assistants and was the first to imagine a village-based monitoring team. The presence of Malagasy and international researchers has strengthened the partnership in a variety of ways, and we appreciate their many contributions. We are grateful to WWF for their support in the early years, and to the Pete and Marion Schwartz Foundation who helped us turn a camp into the field station. LCAOF has steadfastly supported the Bezà Mahafaly Monitoring Team and other activities for the past 20 years. We particularly thank Art Ortenberg and the late Liz Claiborne, who helped keep our optimism and ambitions high even when things were going wrong. We thank Jeannin Ranaivonasy and Isabella Fiorentino for their help in the preparation of this manuscript, and Jacques Pollini, Andry Randrianandrasana, Michael Wells, and three anonymous reviewers for their comments on earlier drafts. We never forget the help and support of the late Robert E. Dewar for all these years. Vololoniaina Rakotozafy and Jeannin Ranaivonasy have made many contributions to the partnership over the years, for which we are enduringly grateful.

\section{REFERENCES}

Agrawal, A. and Gibson, C. C. 1999. Enchantment and disenchantment: the role of community in natural resource conservation. World Development 27, 4: 629-649. (doi:10.1016/S0305-750X(98)00161-2)

Andriamalala, G. \& Gardner, C. J. 2010. L'utilisation du dina comme outil de gouvernance des ressources naturelles: leçons tirés de Velondriake, sud-ouest de Madagascar. Tropical Conservation Science 3, 4: 447-472.

Blanc-Pamard, C. 2009. The Mikea Forest under threat (southwest Madagascar): how public policy leads to conflicting territories. Field Actions Science Reports 3. Available at <http://factsreports.revues.org/341>

Dewar, R. E. and Richard, A. F. 2007. Evolution in the hypervariable environment of Madagascar. Proceedings of the National Academy of Sciences of the United States of America 104, 34: 13723-13727. (doi:10.1073/pnas.0704346104)
Dewar, R. E. and Richard, A. F. 2012. Madagascar: A history of arrivals, what happened, and will happen next. Annual Reviews of Anthropology 41: 495-517. (doi:10.1146/annurev-anthro-092611-145758)

Durbin, J. C., Rakotoniaina, L. J. and Randriamahefasoa, J. 2003. Project Alaotra: using endangered species as flagships for community-based wetland conservation. In: The Natural History of Madagascar. S. M. Goodman and J. P. Benstead (eds.), pp 1551-1555. The University of Chicago Press, Chicago.

Elmqvist, T., Pyykönen, M., Tengö, M., Rakotondrasoa, F., Rabakonandrianina, E. and Radimilahy, C. 2007. Patterns of loss and regeneration of tropical dry forest in Madagascar: the social institutional context. PLOS ONE 2, 5: e402. (doi:10.1371/journal.pone.0000402)

Gezon, L. L. 1997. Institutional structure and the effectiveness of integrated conservation and development projects: case study from Madagascar. Human Organization 56, 4: 462-470.

Gezon, L. L. 2006. Global Visions, Local Landscapes: A Political Ecology of Conservation, Conflict, and Control in Northern Madagascar. Globalization and the Environment Series, Alta Mira Press, Lanham, MD, USA.

Hanson, P. W. 2012. Toward a more transformative participation in the conservation of Madagascar's natural resources. Geoforum 43, 6: 1182-1193. (doi:10.1016/j.geoforum.2012.03.005)

Harris, A. R. 2011. Out of sight but no longer out of mind: a climate of change for marine conservation in Madagascar. Madagascar Conservation \& Development 6, 1: 7-14.

Horning, N. R. 2003. How rules affect conservation outcomes. In: The Natural History of Madagascar. S. M. Goodman and J. P. Benstead (eds.), pp 146-153. The University of Chicago Press, Chicago.

Horning, N. R. 2008. Madagascar's biodiversity conservation challenge: from local to national level dynamics. Environmental Sciences 5, 2: 109-128. (doi:10.1080/15693430801912246)

ILO/FOFIFA/INSTAT. 2001. The commune census of Madagascar by the Ilo program of Cornell University in collaboration with FOFIFA and INSTAT. Available at <http://www.ilo.cornell.edu/ilo/data.html>

Kull, C. A. 2002. Isle of Fire: the Political Ecology of Landscape Burning in Madagascar. The University of Chicago Press, Chicago.

Lingard, M., Raharison, N., Rabakonandrianina, E., Rakotoarisoa, J.-A. and Elmqvist, T. 2003. The role of local taboos in conservation and management of species: the radiated tortoise in southern Madagascar. Conservation and Society 1, 2: 223-246.

Minten, B., Randrianarisoa, J-C. \& Randrianarison, L. (eds.). 2003. Agriculture, pauvreté et politiques économiques à Madagascar. Programme ILO/ FOFIFA. USAID, Cornell, INSTAT, FOFIFA. Available at <http://pdf.usaid. gov/pdf_docs/pnadi994.pdf>

Mittermeier, R. A. 1988. Primate diversity and the tropical forest: case studies from Brazil and Madagascar and the importance of megadiversity countries. In: Biodiversity. E. O. Wilson (ed.), pp 145-154. National Academy Press, Washington, D.C.

Mittermeier, R. A. and Bowles, I. A. 1993. The global environment facility and biodiversity conservation: lessons to date and suggestions for future action. Biodiversity and Conservation 2, 6: 637-655. (doi:10.1007/ BF00051964)

Ormsby, A. and Kaplin, B. A. 2005. A framework for understanding community resident perceptions of Masoala National Park, Madagascar. Environmental Conservation 32, 2: 156-164. (doi:10.1017/ S0376892905002146)

Peters, J. 1998. Transforming the integrated conservation and development project (ICDP) approach: observations from the Ranomafana National Park Project, Madagascar. Journal of Agricultural and Environmental Ethics 11, 1: 17-47. (doi:10.1023/A:1007796628731)

Pollini, J. 2011. The difficult reconciliation of conservation and development objectives: The case of the Malagasy Environmental Action Plan. Human Organization 70, 1: 74-87.

Pollini, J. and Lassoie, J. P. 2011. Trapping farmer communities within global environmental regimes: the case of the GELOSE legislation in Madagascar. Society and Natural Resources 24, 8: 814-830. (doi:10.1080/08941921003782218)

Rabearivony, J., Fanameha, E., Mampiandra, J. and Thorstrom, R. 2008. Taboos and social contracts: tools for ecosystem management lessons from the Manambolomaty Lakes RAMSAR site, western Madagascar. Madagascar Conservation \& Development 3, 1: 7-16. 
Raik, D. B. and Decker, D. J. 2007. A multisector framework for assessing community-based forest management: Lessons from Madagascar. Ecology and Society 12, 1: 14. [online] URL: http://www.ecology andsociety.org/vol12/iss1/art14/

Randriamalala, H. and Liu, Z. 2010. Rosewood of Madagascar: between democracy and conservation. Madagascar Conservation \& Development 5, 1: 11-22.

Rasamimanana, N., Ratsirarson, J. \& Richard, A. F. 2012. Influence de la variabilité climatique sur la phénologie de la forêt de la Réserve Spéciale de Bezà Mahafaly. Malagasy Nature 6: 67-82.

Ratsirarson, J., Randrianarison, J., Ellis, E., Emady, R. J., Efitroarany, J. Ranaivonasy, E., Razanajaonarivalona, H. \& Richard, A. F. 2001. Bezà Mahafaly: écologie et réalités socio-économiques. Série Sciences Biologiques n¹8. CIDST. Ministère de la Recherche Scientifique. Antananarivo. Madagascar.

Ratsirarson, J. 2003. Réserve Spéciale de Bezà Mahafaly. In: The Natural History of Madagascar. S. M. Goodman and J. P. Benstead (eds.), pp 1520-1525. The University of Chicago Press, Chicago.

Ratsirarson, J. 2008. La Réserve Spéciale de Bezà Mahafaly. In: Paysages Naturels et Biodiversité de Madagascar. S. M. Goodman (ed.), pp 615-626. Muséum national d'Histoire naturelle, Paris.

Richard, A. F. and Dewar, R. E. 2001. Politics, negotiation, and conservation: a view from Madagascar. In: African Rain Forest Ecology and Conservation. W. Weber, L. J. T. White, A. Vedder, and L. NaughtonTreves (eds.), pp 535-544. Yale University Press, New Haven, USA.

Sommerville, M., Jones, J. P. G., Rahajaharison, M. and Milner-Gulland, E. J. 2010. The role of fairness and benefit distribution in communitybased Payment for Environmental Services intervention: a case study from Menabe, Madagascar. Ecological Economics 69, 6: 1262-1271. (doi:10.1016/j.ecolecon.2009.11.005)
Sussman, R. W., Green, G. M. and Sussman, L. K. 1994. Satellite imagery, human ecology, anthropology, and deforestation in Madagascar. Human Ecology 22, 3: 333-354. (doi:10.1007/BF02168856)

Sussman, R. W., Richard, A. F., Ratsirarson, J., Sauther, M. L., Brockman, D. K., Gould, L., Lawler, R. and Cuozzo, F. P. 2012. Bezà Mahafaly Special Reserve: Iong-term research on lemurs in southwestern Madagascar. In: Long-term Field Studies of Primates. P. M. Kappeler and D. P. Watts (eds.), pp 45-66. Springer-Verlag, Heidelberg.

Tengö, M., Johansson, K., Rakotondrasoa, F., Lundberg, J., Andriamaherilala J.-A., Rakotoarisoa, J.-A. and Elmqvist, T. 2007. Taboos and forest governance: informal protection of hot spot dry forest in southern Madagascar. Ambio 36, 8: 683-691. (doi:10.1579/00447447(2007)36[683:TAFGIP]2.0.CO;2)

Toillier, A., Serpantié, G., Hervé, D. and Lardon, S. 2011. Livelihood strategies and land use changes in response to conservation: pitfalls of community-based forest management in Madagascar. Journal of Sustainable Forestry 30, 1-2: 20-56. (doi:10.1080/10549811003742357)

Wells, M. and Brandon, K. 1992. People and Parks: Linking Protected Area Management with Local Communities. The World Bank, Washington, D.C.

West, P., Igoe, J. and Brockington, D. 2006. Parks and peoples: the social impact of protected areas. Annual Review of Anthropology 35: 251-277. (doi:10.1146/annurev.anthro.35.081705.123308)

Western, D. and Wright, R. M. 1994. The background to community-based conservation. In: Natural Connections: Perspectives in Communitybased Conservation. D. Western and R. M. Wright (eds.), pp 1-12. Island Press, Washington, D.C. 